\author{
제주도 지하수위의 변화와 지하수 함양부피 \\ 박원배 $\cdot$ 김기표 ${ }^{1)} \cdot$ 이준호 ${ }^{2)} \cdot$ 문덕철 $^{1)} \cdot$ 김수정 ${ }^{3)} \cdot$ 고기원(1) $\cdot$ 방성준 ${ }^{2)} \cdot$ 방익찬 $^{2)^{*}}$ \\ 제주발전연구원, ${ }^{1}$ 제주도특별자치도수자원본부, ${ }^{2}$ 제주대학교 지구해양과학과, \\ ${ }^{3)}$ 제주특별자치도보건환경연구원, ${ }^{4}$ 제주하이테크산업진흥원 \\ (2011년 1월 31일 접수; 2011년 4월 1일 수정; 2011년 5월 2일 채택)
}

\title{
Variation of Groundwater Level and Recharge Volume in Jeju Island
}

\author{
Won-Bea Park, Gee-Pyo Kim", Joon Ho Lee ${ }^{2)}$, Duk-Chul Moon ${ }^{1)}$, Soo-Jeong Kim ${ }^{3)}$, \\ Gi Won Koh ${ }^{4)}$, Sung Jun Pang ${ }^{2)}$, Ig-Chan Pang ${ }^{2)^{*}}$ \\ Jeju Development Institute, Jeju 690-029, Korea \\ ${ }^{1)}$ Jeju-Special Self-Governing Province Water Resource Headquarter, Jeju 602-702, Korea \\ ${ }^{2}$ Department of Earth and Marine Science, Jeju National University, Jeju 690-756, Korea \\ ${ }^{3)}$ Jeju-Special Self-Governing Province Research Institute of Public Health and Environment, Jeju 690-817, Korea \\ ${ }^{4)}$ Jeju Leading Industry Development for Economic Region, Jeju 690-022, Korea \\ (Manuscript received 31 January, 2011; revised 1 April, 2011; accepted 2 May, 2011)
}

\begin{abstract}
The variation of groundwater level in Jeju Island is analyzed with the data of precipitation observed from 48 monitoring post and groundwater level observed from 84 monitoring wells during 2001 to 2009 . The groundwater level rises in summer and falls in winter. The rise of groundwater level by precipitation is fast and small in the eastern region and slow and large in the western region. However, the speed of fall during the period of no rain is slower in the eastern region than in the western region. It tells that permeability is greater in the eastern region than in the western region. In this paper, we set up the base level of groundwater and calculate recharge volume between the base level and groundwater surface. During the period, the average recharge volume was $9.83 \times 10^{9} \mathrm{~m}^{3}$ and the maximum recharge volume was $2.667 \times 10^{10} \mathrm{~m}^{3}$ after the typhoon Nari. With these volume and the recharge masses obtained by applying the recharge ratio of $46.1 \%$, estimated by Jeju Province (2003), the porous ratio over the whole Jeju Island is $16.8 \%$ in average and $4.6 \%$ in the case of maximum recharge volume just after typhoon Nari. A large difference in the two ratios is because that it takes time for groundwater permeated through the ground just after rain fall to fill up the empty porous part. Although the porous ratios over the whole Jeju Island obtained in this way has a large error, they give us the advantage to roughly estimate the amount of recharged groundwater mass directly from observing the groundwater level.
\end{abstract}

Key Words : Groundwater, Recharge volume, Groundwater base level, Porous ratio, Jeju Island

*Corresponding author : Ig-Chan Pang, Department of Earth and Marine Science, Jeju National University, Jeju 690-756, Korea

Phone: +82-64-754-3434

E-mail: pangig@cheju.ac.kr

\section{1. 서 론}

제주도는 정부의 광역경제권 선도산업에서 물산업 경제권으로 선정된 것을 계기로 2차 산업이 취약한 제 주도의 산업구조를 개선시킬 수 있는 성장 동력으로 
물산업을 육성하기로 하였다. 제주도가 물산업의 선 도경제권으로 선정된 것은 고품질의 화산 암반수를 다량으로 보유하고 있기 때문이다. 제주도는 제주워 터를 글로벌 브랜드로 육성하여 2017년에는 연 1조원 매출 달성을 목표로 하고 있으며 장차 물산업이 제주 도 경제에서 감귤산업을 능가하는 산업으로 기대하고 있다. 이와 같은 규모로 물산업을 육성할 경우 지하수 의 수요가 급증하게 됨으로써 지하수의 안정적인 공 급을 위해 보다 과학적이고 체계적인 관리가 필요할 것이다. 본 연구의 목표는 제주도 지하수의 공급원인 강수량과 지하수위의 관계를 분석하여 제주도 지하수 를 효율적로 이용하는 데 필요한 정보를 제공하는 데 있다.

2003 년도에 제주도는 강수량에서 증발산량과 지표 를 통해 바로 바다로 유출되는 직접유출량을 제하는 방법으로 제주도 지하수의 함양량을 총강수량의 $46.1 \%$ 인 1,581 백만 $\mathrm{m}^{3} /$ 년으로 산정하였다 (제주도, 한국수자원공사, 2003). 이 방법은 강수량, 증발산량, 유출량을 계산하여 지하수 함양량을 구하는 간접적인 방법이기 때문에 이에 따른 오차가 생기기 마련이다. 최근에는 강수량과 지하수위의 체계적인 모니터링으 로 자료가 많이 축적되면서 지하수위의 변화로부터 강수 후 지하수가 채워진 지각의 부피(함양부피)를 직 접 계산하는 것이 가능하게 되었다. 그동안 기상청은 $\mathrm{AWS}$ 관측소를 25 개 운영하며 중산간 지역을 포함한 제주도 전역의 강수량을 측정하고 있고 제주특별자치 도 소방방재본부에서는 재난방지용으로 강수량 관측 소 48 개소를 운영하고 있다. 또한, 제주특별자치도수 자원본부에서 지하수 관리를 위해 100 개소 이상의 관 측정에서 실시간으로 지하수위를 측정하고 있다. 이 정도의 관측망이면 제주도 전역에 대한 강수와 지하 수위의 관계와 강수에 의한 지하수 함양부피를 구할 수 있다. 이 연구에서는 이러한 자료를 수집하여 강수 량과 지하수위의 관계를 분석하고 지하수위의 변동으 로부터 제주도 전역과 지역별로 지하수 함양부피를 계산하고자 한다.

강수에 의한 지하수의 함양부피를 지하수면으로부 터 구하기 위해서는 지하수위 기준면이 필요하다. 지 하수위 기준면은 강수에 의해 상승한 지하수면이 무 강수 시 가장 낮게 하강하는 지하수면으로서 이 논문
에서는 관정별로 강수에 의해 지하수위가 높아진 후 다시 되돌아오는 안정적인 기준수위를 정한 후에 이 수위들을 연결하여 지하수위 기준면을 구하였다. 함 양부피는 이 기준면과 강수 시 상승한 지하수면 사이 의 부피로 계산할 수 있으며 관측정에서 지하수위가 관측되면 제주도 전역 또는 지역별 지하수 함양부피 를 계산할 수 있다. 이렇게 구한 함양부피로부터 바로 함양량을 구할 수는 없지만 함양부피를 비교함으로서 상대적인 함양량을 추정할 수 있으며 지역별 지하수 분 포 상태를 판단할 수 있다. 또한 지하수위 기준면은 함 양부피를 구하는 데뿐만 아니라 장기간 가뭄 시 지하수 사용량 관리에도 필요한 기준이 될 수 있을 것이다.

지하수위의 변화로부터 지하수 함양량을 추정하는 방법은 김 등(2008), 이(2007), 김 등(2004), 문과 우 (2001), 문 등(2002), 박(2002), 박 등(1999), 최와 안 (1998), 김 등(1998), Healy 등(2002), Moon 등 (2004), Scanlon 등(2002), Solomon 등(1991) 등에 의 해 연구되었으나 제주도에서는 아직 많은 연구가 이 루어지지 않았다. 이 방법은 지하수위로부터 지하수 가 채워진 함양부피를 직접 계산하는 방법으로 강수 량에서 증발산량과 직접유출량을 제하여 함양량을 구 하는 간접적인 방법에 비해 강점을 가지고 있기는 하지 만, 함양부피 중 어느 정도가 지하수로 채워져 있는지 를 알려주는 공극률을 현재로서는 정확하게 알 수 없기 때문에 역시 한계가 있다. 이 논문에서는 지하수위의 변화로부터 구한 함양부피와 2003년 제주도 수문지질 및 지하수자원 종합조사 $\mathrm{I}$ (제주도 - 한국수자원공사, 2003)에서 산출한 함양량을 근거로 제주도 전역의 평 균 공극률을 산정해 보았다. 지하수위 변화로부터 지하 수 함양부피를 구하고 지하수로 채워진 공극률을 계산 하는 것은 제주도의 지하수 함양량 산정을 다른 시각으 로 접근하는 계기가 될 것이라고 생각한다.

지역별 함양부피는 강수량에 따른 지하수위의 상 승 정도와 가뭄 시 지하수위의 하강 정도에 관계가 있 기 때문에 이 연구에서는 강수와 무강수 시 지하수위 의 반응을 지역별로 분석해 보았다. 이러한 결과들은 강수량에 따른 지하수위의 변화와 지속적인 가뭄에 의한 지하수위의 변화 등을 예측하게 해 주기 때문에, 지하수 이용 및 개발, 효율적 수자원관리 방안을 도출 하는 데 기초자료로 사용될 수 있을 것이다. 


\section{2. 자료 및 방법}

연구에 사용된 강수량 자료는 1992년부터 2009년 7 월까지의 자료이며 지하수위 자료는 자동관측 시스 템이 구축된 2001년 1월 1일부터 2009년 7월 31일까 지의 자료이다. 강수량 관측은 기상청관할 4 개 기상관 측소와 최근 설치된 중산간 지역의 $\mathrm{AWS}$, 제주특별 자치도 소방방재본부에서 운영하는 관측들이 있으며 강수량이 관측된 총 69개 지점 중 1992-2009년 동안 꾸준히 관측된 48 개 지점의 강수량 자료만 선택하여 사용하였고(Fig. 1), 지하수위가 관측된 총 126 개 관 측정 중 기준면(3.2절 참조)을 산정할 때는 102 개소 자료를 사용하였고 다른 분석에는 관측기간이 짧거나 지하수위의 변동이 이해하기 힘든 관측정을 제외한 84개를 선택하여 사용하였다(Fig. 2). 그러나 선정된 84 개 관측정도 설치되기 전이거나 설치된 후에도 결 측된 경우들이 있어 실제로는 84 개 보다 작다. 분석에 사용된 관측정의 개수는 Fig. 3 과 같다. 강수량 관측소 및 지하수위 관측정의 고도를 파악하기 위해서 미국
$\mathrm{NGA}$ 의 DTED(2004) Level 1 자료를 이용하였다. 이 자료는 2000년 위성고도계로부터 얻은 자료를 이용 하여 평균해면을 수직 기준면으로 정하고 WGS84 경 위도 좌표로 나타낸 30 초간격의 육상 표고 자료이다. 분석 편의상 제주도를 Fig. 1과 Fig. 2에서와 같이 8개 구역으로 나누어 분석하였다.

제주도 전역의 평균 강수량이나 평균 지하수 함양 부피(3.4절 참조) 등을 산정할 때에는 단순평균과 관 측자료들을 제주도 전역에 걸쳐 내삽한 후에 평균한 내삽평균으로 구하였다. 예를 들어 년강수량의 평균 을 구할 때 각 강수량 관측소의 년강수량 자료를 제주 도 전역에 걸쳐 내삽한 것이 Fig. 5이다. 강수량 관측 소는 제주도 전역에 골고루 퍼져 분포하기 때문에 (Fig. 1) 이렇게 구한 내삽평균 값은 단순평균 값과 거 의 일치한다. 그러나 지하수위 관측정은 고도가 낮은 해안가에 많이 분포하고 고도가 높은 중산간 지역에 는 수가 적으며 고도가 매우 높은 한라산 국립공원 주 변에는 설치되어 있는 관측정이 없다(Fig. 2). 이와 같

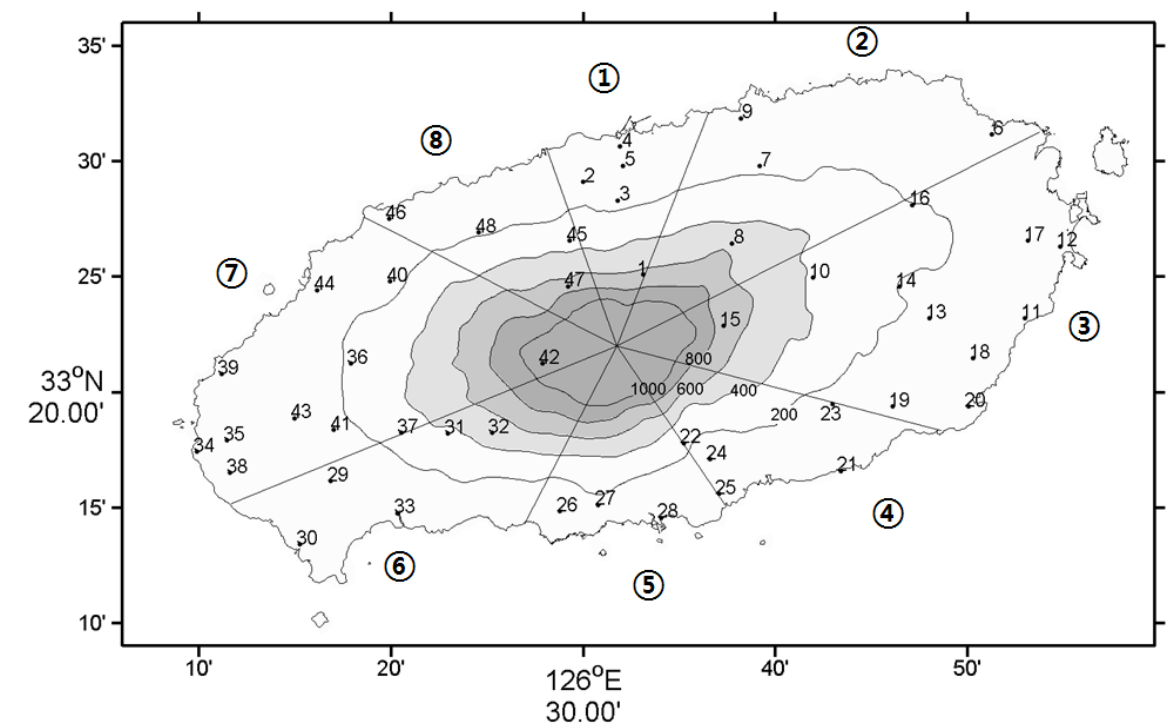

Fig. 1. Maps of monitoring stations for precipitation and 8 sections. Numbers for contour indicate altitudes above mean sea level in meters. The monitoring stations for precipitation are 1 Gwaneumsa, 2 Sinjeju, 3 Odeungdong, 4 Jeju, 5 Jejusi, 6 Gujwa, 7 Daeheul, 8 Bonggae, 9 Jocheon, 10 Gyorae, 11 Sungsan, 12 Sungsangosung, 13 Sungup-1, 14 Sungup-2, 15 Sungpanak, 16 Songdang, 17 Susan-1, 18 Sinpyeong, 19 Tosan-1, 20 Pyosun, 21 Namweon, 22 Donnaeko, 23 Sumang, 24 Harye, 25 Hyodon, 26 Daecheon, 27 Beophwan, 28 Seogwuipo, 29 Gueok, 30 Daejung, 31 Sangcheon, 32 Saekdal, 33 Hwasun, 34 Gosan, 35 Gosan-2, 36 Geumak, 37 Donggwang, 38 Sindo, 39 Sinchang, 40 Eoeum, 41 Jeoji, 42 Cheonbakgoji, 43 Cheongsu, 44 Hanlim, 45 Nohyong, 46 Aewol, 47 Eoseungsang, 48 Hangpaduri. 
이 관측정의 분포가 불균질할 경우에는 단순평균과 내삽평균이 많이 다르며 내삽평균이 실제와 더 가깝 게 된다. 따라서 이 논문에서는 제주도 전지역의 평균 을 구할 때는 내삽평균을 주로 사용하였다. 내삽할 때
사용한 격자는 제주도를 동서와 남북으로 각각 0.005 도 간격으로 나누어 만들었으며 한 격자의 면적은 약 $2.59 \times 10^{5} \mathrm{~m}^{2}$ (약 $500 \mathrm{~m}$ 간격)이다.

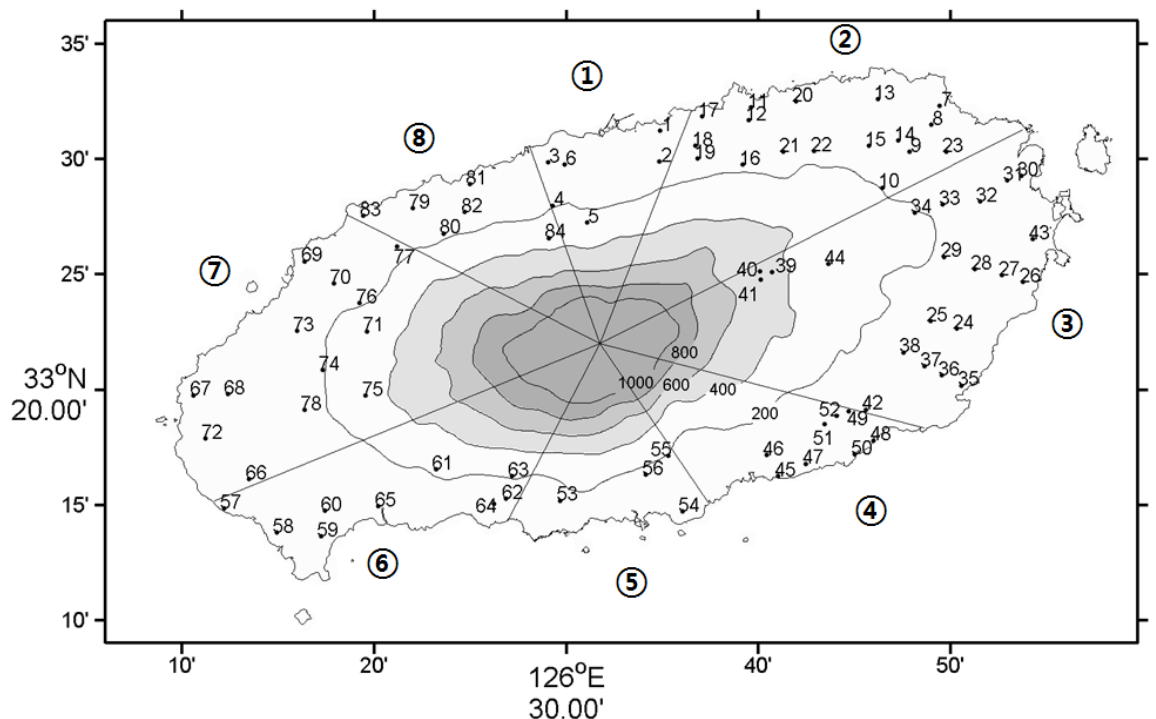

Fig. 2. Maps of monitoring stations for groundwater level and 8 sections for analyses. Numbers for contour indicate altitudes above sea level in meters. The monitoring stations for groundwater level are 1 Samyang-1, 2 Samyang-2, 3 Yongdam-1, 4 Yongdam-2, 5 Ora, 6 Gonghang, 7 Handong-1, 8 Handong-2, 9 Handong-3, 10 Handong-4, 11 Hamduk-1, 12 Hamduk-2, 13 Gujwa-1, 14 Gujwa-2, 15 Gujwa-3, 16 Daeheul, 17 Sinchon-1, 18 Sinchon-2, 19 Sinchon-3, 20 Jocheon-1, 21 Jocheon-2, 22 Jocheon-3, 23 Pyeongdae, 24 Samdal-2, 25 Samdal-3, 26 Susan-1, 27 Susan-2, 28 Susan-3, 29 Susan-4, 30 Jongdal-1, 31 Jongdal-2, 32 Jongdal-3, 33 Jongdal-4, 34 Jongdal-5, 35 Hacheon-1, 36 Hacheon-2, 37 Hacheon-3, 38 Hacheon-4, 39 Gyorae-1, 40 Gyorae-2, 41 Gyorae-3, 42 Sinheung-3, 43 Gosung, 44 Jocheon, 45 Wimi-1, 46 Wimi-2, 47 Namwon, 48 Sinheung-1, 49 Sinheung-2, 50 Taeheung-1, 51 Taeheung-2, 52 Taeheung-3, 53 Yongheung, 54 Topyeong-1, 55 Topyeong-2, 56 Dongheung, 57 Mureung-1, 58 Sangmo-1, 59 Sangmo-2, 60 Ansung, 61 Sangye-2, 62 Hoesu-1, 63 Hoesu-2, 64 Jungmun-1, 65 Hwasun, 66 Mureung-2, 67 Yongsu-1, 68 Yongsu-2, 69 Hanlim-1, 70 Hanlim-2, 71 Wonjongjang-1, 72 Gosan-2, 73 Myongwol, 74 Gumak-1, 75 Gumak-2, 76 Bongsung, 77 Sangga-2, 78 Hankyong, 79 Sineom, 80 Jangjeon-1, 81 Hagwi-1, 82 Hagwi-2, 83 Aewol, 84 Nohyong.

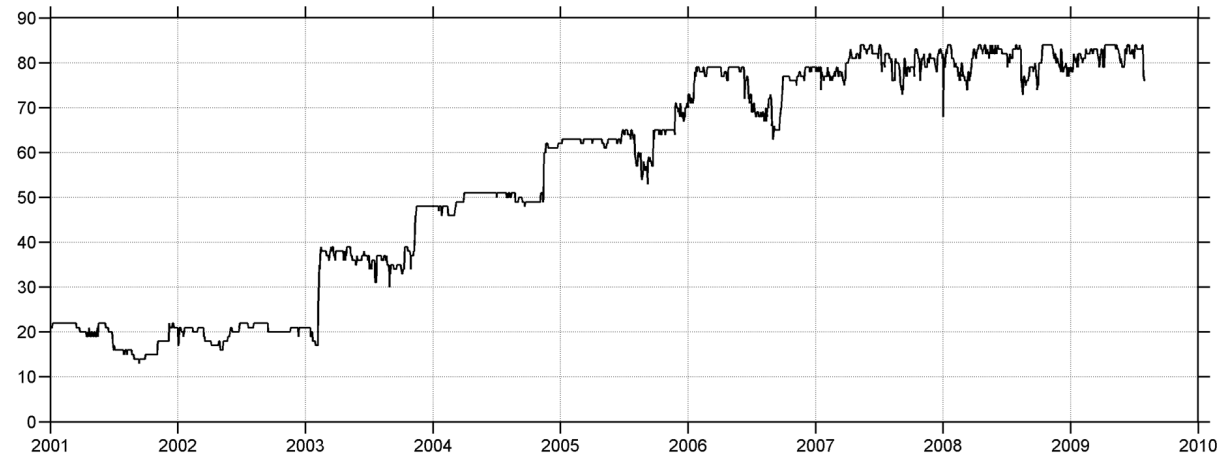

Fig. 3. Numbers of the monitoring stations for groundwater level to be used for analyses The maximum number of the monitoring stations is 84 . 


\section{3. 결 과}

\section{1. 제주도 평균 강수량}

Fig. 4는 1992년 1월 1일부터 2009년 7월 31일까지 48 개 강수량 관측소의 일강수량을 평균하여 얻은 평 균 일강수량(A), 48 개 관측소의 강수량을 제주도 전 체에 걸쳐 공간적으로 내삽한 후에 평균하여 얻은 평 균 일강수량 $(\mathrm{B}),(\mathrm{B})$ 에서 $(\mathrm{A})$ 를 뺀 값 $(\mathrm{C})$, 그리고 년강 수량(D)을 나타낸 것이다. 단순 평균과 내삽 평균으로 산정된 두 일평균 강수량의 차이는 평균 약 $10 \mathrm{~mm}$ 로 서, 내삽하여 구한 강수량이 더 많게 산정되었다(Fig. 4(C)). (D)는 제주도의 평균 년강수량을 나타낸 것인 데 48 개 관측소의 강수량을 단순히 평균하여 구한 단 순 평균(왼쪽 막대)과 이들을 제주도 전역에 걸쳐 내
삽하여 구한 내삽 평균(오른쪽 막대)을 구분하여 표시 하였다. 제주도의 강수량은 고도가 높아질수록 많아 지는데 강수량 관측소의 위치는 고도가 높은 지역보 다 고도가 낮은 지역에 많기 때문에 관측소의 강수량 을 단순히 평균한 값보다 제주도 전지역에 걸쳐 공간 적으로 내삽한 후에 평균한 값이 약간 많게 되며 실제 강수량에 가깝다고 볼 수 있다(Fig. 1).

평균 일강수량을 보면 대부분 여름에 편중되어 있 는 하계 집중형 강수형태를 보여준다(Fig. 4(A)와 (B)). 이와 같은 원인으로는 6월 하순부터 시작되는 장마와 함께 6 월에서 10 월까지 내습하는 태풍의 영향 을 손꼽을 수가 있다. 또한, 우리나라는 국지적인 집중 호우가 자주 발생하는데 이러한 집중호우는 장마전선 이나 저기압이 우리나라를 지날 때 습윤한 남서기류
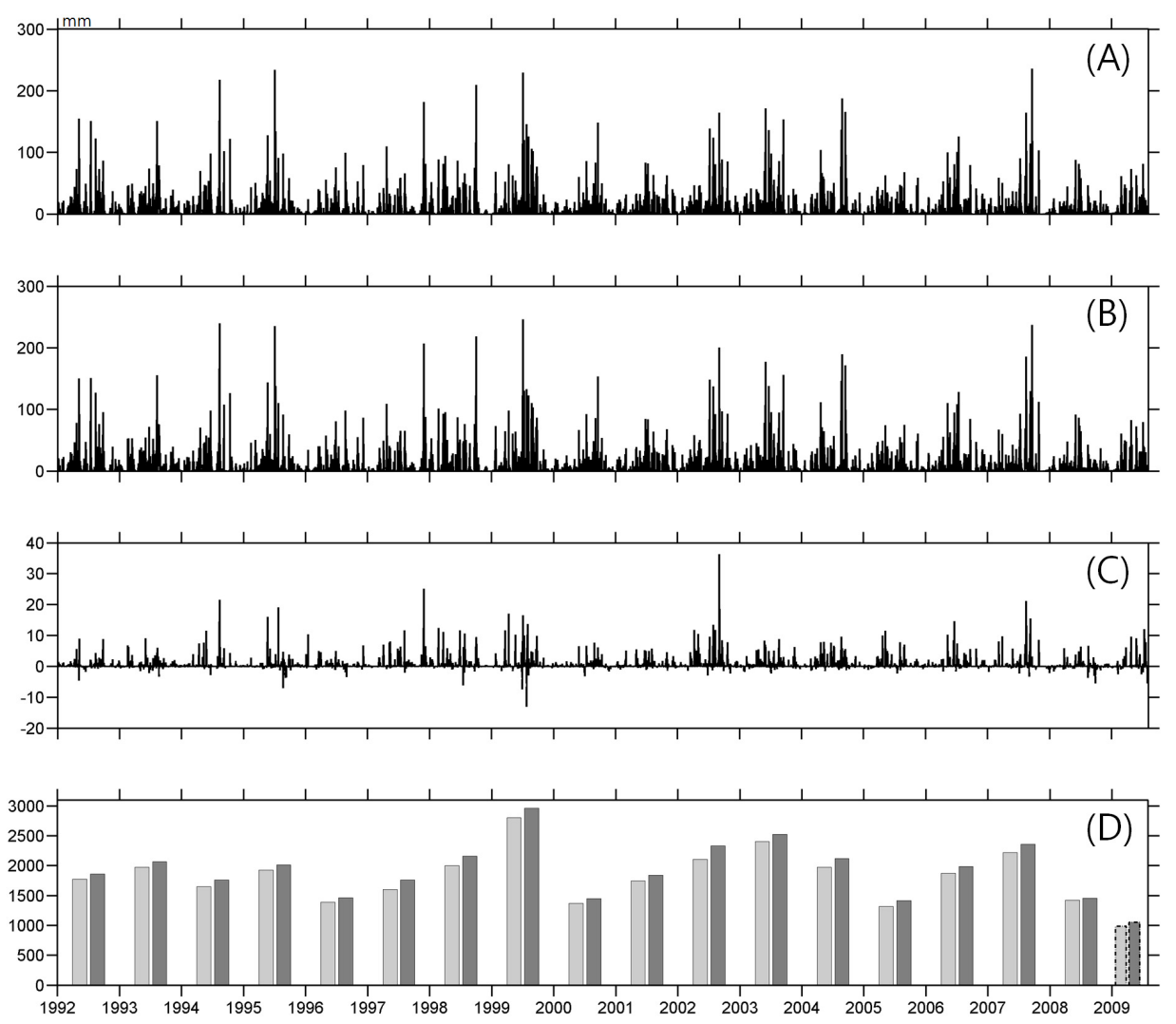

Fig. 4. Daily precipitation estimated by (A) simple average, (B) average after spatially interpolating the precipitation data from 48 monitoring stations during the period of January 1, 1992 to July 31, 2009, (C) difference between (B) and (A) (i.e., $(\mathrm{C})=(\mathrm{B})-(\mathrm{A})$ ), and (D) yearly mean precipitation (Left and right sticks are yearly precipitation estimated by simple average and average after spatially interpolation, respectively.). 
가 유입되거나 태풍이 통과할 때 자주 발생한다(제주 특별자치도, 2010). 년강수량은 적게는 약 $1,500 \mathrm{~mm}$ 에서 많게는 1999 년의 약 $3,000 \mathrm{~mm}$ 까지 편차가 심하 며 1992-2009년 동안의 년강수량 평균은 내삽으로 계 산한 경우 $1,973 \mathrm{~mm}$ 으로 기존의 연구결과와 일치한 다(Fig. 4D). 2003년도 제주도 수문지질 및 지하수자 원 종합조사(III)에서 산정한 연평균 강수량은 기상청 관할 4개관측소 및 제주도 소방방재본부에서 운영하 는 24 개 관측소의 10 년간(1993년 2002년) 강우자료 를 이용하여 면적강수량을 $1,975 \mathrm{~mm}$ 로 계산되었다 (제주도, 한국수자원공사, 2003). 1999년에 강수량이 특히 많았던 것은 제주도 지역을 지나간 태풍이 많았 었기 때문이다.

1992년부터 2008년 동안 48개 강수량 관측점의 지 점별 평균 년강수량은 Table 1 과 같다. 지점별로 강수
량을 살펴보면 성판악이 $3,727 \mathrm{~mm}$ 로 가장 많았고 고 산2 지역이 $1,120 \mathrm{~mm}$ 로 가장 적었으며 이 두지역간 의 차이는 약 $2,600 \mathrm{~mm}$ 로 큰 편차를 보였다. 제주도 의 년평균 강수량이 $1,973 \mathrm{~mm}$ 인 것을 감안하면 이러 한 두지역간의 편차는 상당히 큰 양임을 알 수 있다. 성판악의 년강수량이 많은 것은 고도가 높기 때문인 데, 성판악보다 고도가 높은 천백고지보다도 년강수 량이 많은 것은 강수량이 집중되는 여름철의 주 바람 방향이 남동풍이기 때문이다. 바람방향이 남동풍일 때 성판악은 풍상 지역에 해당하는데 비해 천백고지 는 풍하 지역에 해당한다. 이에 따른 푄현상으로 인해 풍하 지역인 천백고지보다 풍상 지역인 성판악에 강 수량이 많아진 것이다.

구역별로 보면 4구역이 2,294 mm로 가장 많으며 7 구역이 $1,400 \mathrm{~mm}$ 로 가장 적다. 제주지역의 년평균 강

Table 1. Yearly mean precipitation from 1992 to 2008

\begin{tabular}{|c|c|c|c|c|c|c|c|}
\hline \multicolumn{2}{|c|}{ Section } & \multirow{2}{*}{$\begin{array}{c}\text { precipitation } \\
(\mathrm{mm})\end{array}$} & \multirow{2}{*}{$\begin{aligned} \begin{array}{l}\text { Height } \\
(\mathrm{m})\end{array} & 578\end{aligned}$} & \multicolumn{2}{|c|}{ Section } & \multirow{2}{*}{$\begin{array}{c}\text { Precipitation } \\
\text { (mm) }\end{array}$} & \multirow{2}{*}{$\begin{array}{l}\begin{array}{l}\text { Height } \\
(\mathrm{m})\end{array} \\
123\end{array}$} \\
\hline \multirow{6}{*}{1} & Gwaneumsa & & & 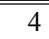 & Mean & & \\
\hline & Sinjeju & 1,637 & 97 & \multirow{4}{*}{5} & \multirow{3}{*}{$\begin{array}{l}\text { Daecheon } \\
\text { Beophwan } \\
\text { Seogwuipo }\end{array}$} & 1,856 & 81 \\
\hline & Odeungdong & 1,677 & 142 & & & 1,768 & 140 \\
\hline & Jeju & 1,494 & 20 & & & 1,927 & 50 \\
\hline & Jejusi & 1,421 & 62 & & Mean & 1,850 & 88 \\
\hline & Mean & 1,752 & 180 & \multirow{2}{*}{\multicolumn{2}{|c|}{$\begin{array}{l}\text { Gueok } \\
\text { Daejung }\end{array}$}} & 1,475 & 70 \\
\hline \multirow{5}{*}{2} & Gujwa & 1,573 & 25 & & & 1,299 & 13 \\
\hline & Daeheul & 1,735 & 145 & \multirow{4}{*}{6} & \multirow{2}{*}{$\begin{array}{l}\text { Sangcheon } \\
\text { Saekdal }\end{array}$} & 1,878 & 368 \\
\hline & Bonggae & 2,362 & 501 & & & 2,463 & 516 \\
\hline & Jocheon & 1,285 & 6 & & Hwasun & 1,499 & 46 \\
\hline & Mean & 1,739 & 169 & & Mean & 1723 & 203 \\
\hline \multirow{12}{*}{3} & Gyorae & 2,670 & 400 & \multirow{12}{*}{7} & Gosan & 1,148 & 61 \\
\hline & Sungsan & 1,999 & 18 & & Gosan-2 & 1,120 & 24 \\
\hline & Sungsangosung & 1,759 & 13 & & Geumak & 1,426 & 212 \\
\hline & Sungup-1 & 2,620 & 131 & & Donggwang & 1,641 & 283 \\
\hline & Sungup-2 & 2,322 & 194 & & Sindo & 1,296 & 35 \\
\hline & Sungpanak & 3,727 & 763 & & Sinchang & 1,184 & 14 \\
\hline & Songdang & 2,117 & 197 & & Eoeum & 1,219 & 127 \\
\hline & Susan-1 & 2,042 & 42 & & Jeoji & 1,220 & 150 \\
\hline & Sinpyeong & 2,238 & 60 & & Cheonbakgoji & 2,542 & 1098 \\
\hline & Tosan-1 & 2,444 & 86 & & Cheongsu & 1,447 & 101 \\
\hline & Pyosun & 1,974 & 14 & & Hanlim & 1,156 & 22 \\
\hline & Mean & 1,931 & 174 & & Mean & 1,400 & 193 \\
\hline \multirow{5}{*}{4} & Namweon & 2,002 & 19 & \multirow{5}{*}{8} & Nohyong & 1,861 & 285 \\
\hline & Donnaeko & 2,633 & 255 & & Aewol & 1,213 & 36 \\
\hline & Sumang & 2,359 & 158 & & Eoseungsang & 2,352 & 612 \\
\hline & Harye & 2,549 & 141 & & Hangpaduri & 1,325 & 165 \\
\hline & Hyodon & 1,925 & 42 & & Mean & 1,688 & 275 \\
\hline
\end{tabular}


수량 분포는 Fig. 5 와 같다. 북쪽과 서쪽 해안지역의 강수량은 1,200-1,600 mm로 작은데 비해 남쪽과 동 쪽의 해안 지방은 $2,000 \mathrm{~mm}$ 정도로 높다. 해안지역에 서는 강수량이 적고 고도가 높아질수록 강수량이 많 아지는데 한라산 부근에는 약 $3,600 \mathrm{~mm}$ 이상인 것으 로 나타났다. 한라산을 중심으로 남동쪽 지역이 다른 지역에 비해 강수량이 많은 것은 역시 비가 많이 오는 여름철에 바람의 방향이 남동풍이고 단열팽창에 따른 푄현상 때문으로 추정된다. 같은 이유로 한라산의 북 서지역에 해당하는 7구역과 8 구역의 년강수량은 작다.

그림으로 나타내지는 않았지만 각 지점별 강수량 변화를 보면 제주도 전역에 걸쳐 대체로 비슷하다. 특 히, 많은 강수량을 보이는 시기에는 제주도 전역에 걸 쳐 강수량이 비슷한데 이것은 많은 강수량을 뿌리는 기단의 규모가 제주도에 비해 크기 때문이며, 이에 반 해 강수량이 적을 때 나타나는 지역별 차이는 기단의 규모가 작은 경우이거나 지역별 지형의 변화에 의해 국지적으로 발생하는 현상 때문으로 판단된다.

\section{2. 지하수위 기준면}

강수에 의한 지하수위의 상승 정도나 지하수 함양
부피를 구하기 위해서는 지하수위의 기준면이 필요하 다. 지하수위 기준면은 각 관측정에서 강수에 의해 지 하수위가 높아진 후, 다시 안정적으로 되돌아오는 기 준수위를 정한 후 그 수위들을 제주도 전역으로 연결 한 면이다. 각 관측정에서 기준수위를 정한 예를 들어 보면 Fig. 6과 같다. 조천 관측정에서는 지하수위가 변 동하여 안정된 수위로 돌아오는 기준수위를 약 $0.5 \mathrm{~m}$ 로 정할 수 있다. 그러나 지하수위의 관측기간이 기준 수위를 정하기에 충분히 길지 않거나 길더라도 지하 수위의 변화가 불규칙하여 기준수위를 정하기가 어려 운 경우도 있다. 이러한 경우들은 제외하고 총 126 개 관측정 중 102 개 관측정에서 정한 기준수위를 연결하 여 제주도 전역의 지하수위 기준면을 작성한 것이 Fig. 7이다. 기준면을 정할 때 관측정을 많이 사용한 이유는 관측정이 거의 없는 높은 고도의 지역에서는 관측정의 유무에 따라 기준면의 분포가 달라지기 때 문에 오차를 줄이기 위함이다. 기준면은 모든 기간 동 안 가장 낮은 수위를 각 관정에서 정한 후 이들을 연결 한 면이기 때문에 임의의 시각에 실제로 나타날 수 있 는 면은 아니며 실제 나타나는 지하수면보다는 대부 분 낮게 된다. Fig. 7에 표시된 지하수위 기준면의 분

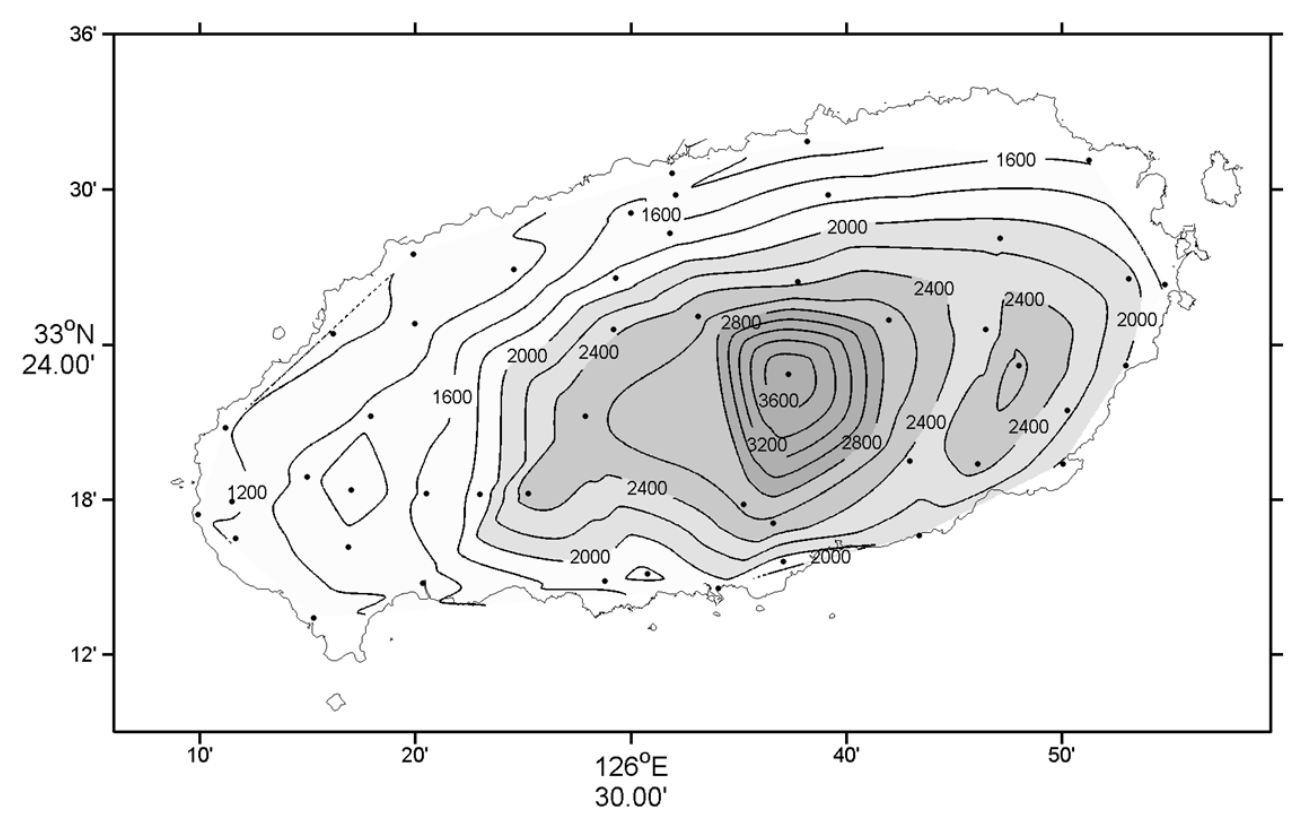

Fig. 5. Distribution of yearly mean precipitation from 1992 to 2008. Dark coloured zone is the area with over 2000mm yearly mean precipitation. 

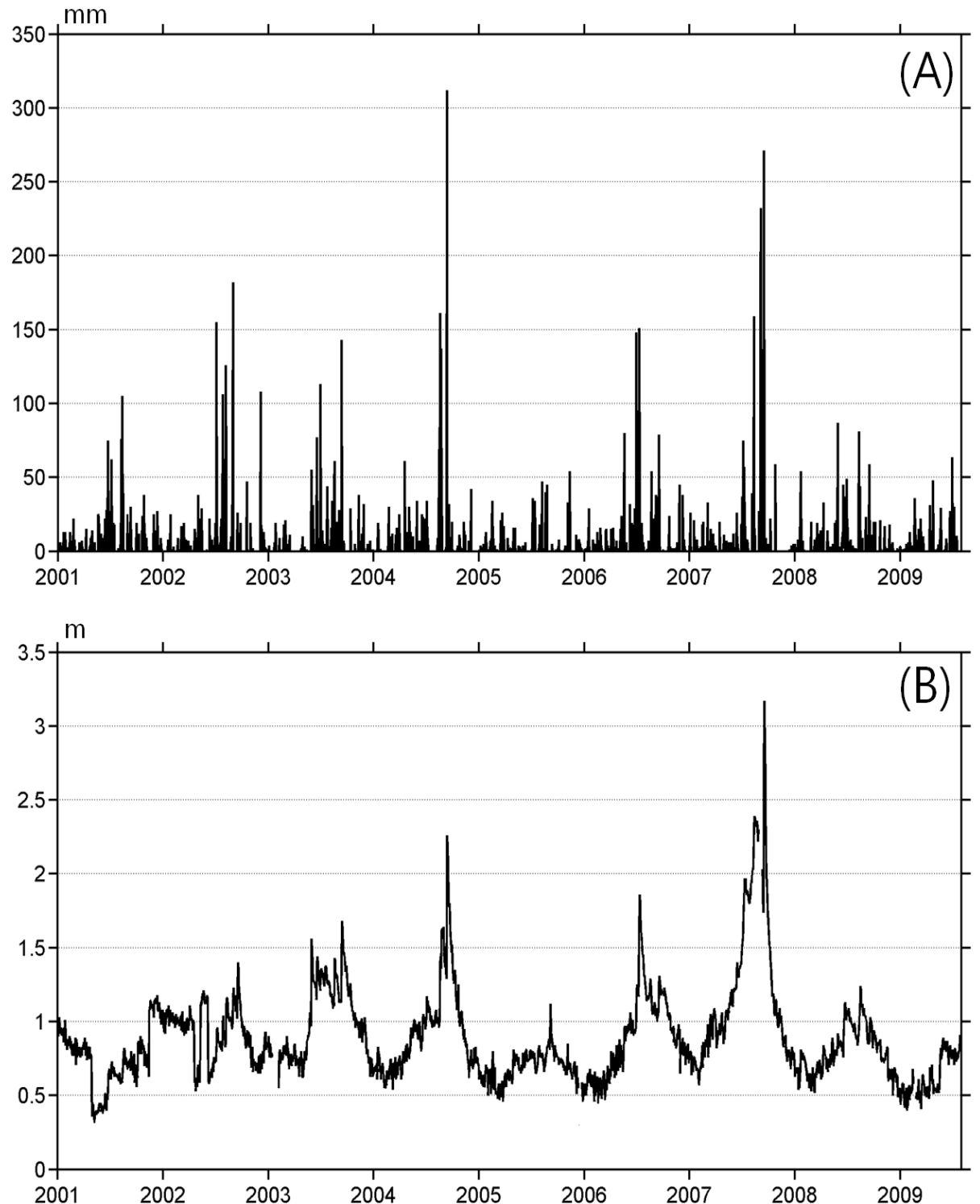

Fig. 6. (A) Daily precipitation and (B) groundwater level variation in Jocheon monitoring well from January 1, 2001 to July 31, 2009.

포를 보면 $50 \mathrm{~m}$ 이하의 기준수위는 동쪽에서 폭 넓게 분포하며 남쪽에서는 폭이 매우 좁다. 중산간 지역에 서는 기준면의 고도가 상승하고 있지만 전체 분포를 정확하게 규명해 내기 위해서는 관측정의 수가 충분 하지 않다. 특히 한라산이 있는 고지대 지역에는 관측 정이 없어 한라산 주변의 기준수위로 내삽되었기 때
문에 지하수위 기준면이 한라산 서쪽에 비해 낮게 구 해졌으며 오차를 수반할 수도 있을 것으로 판단된다. 이러한 문제에도 불구하고 Fig. 7은 제주도 지하수의 기준수위 분포를 개략적으로 가름하게 해 주며, 향후 중산간 지역과 고지대의 자료가 축적 되는대로 보완 해야 할 것이다. 


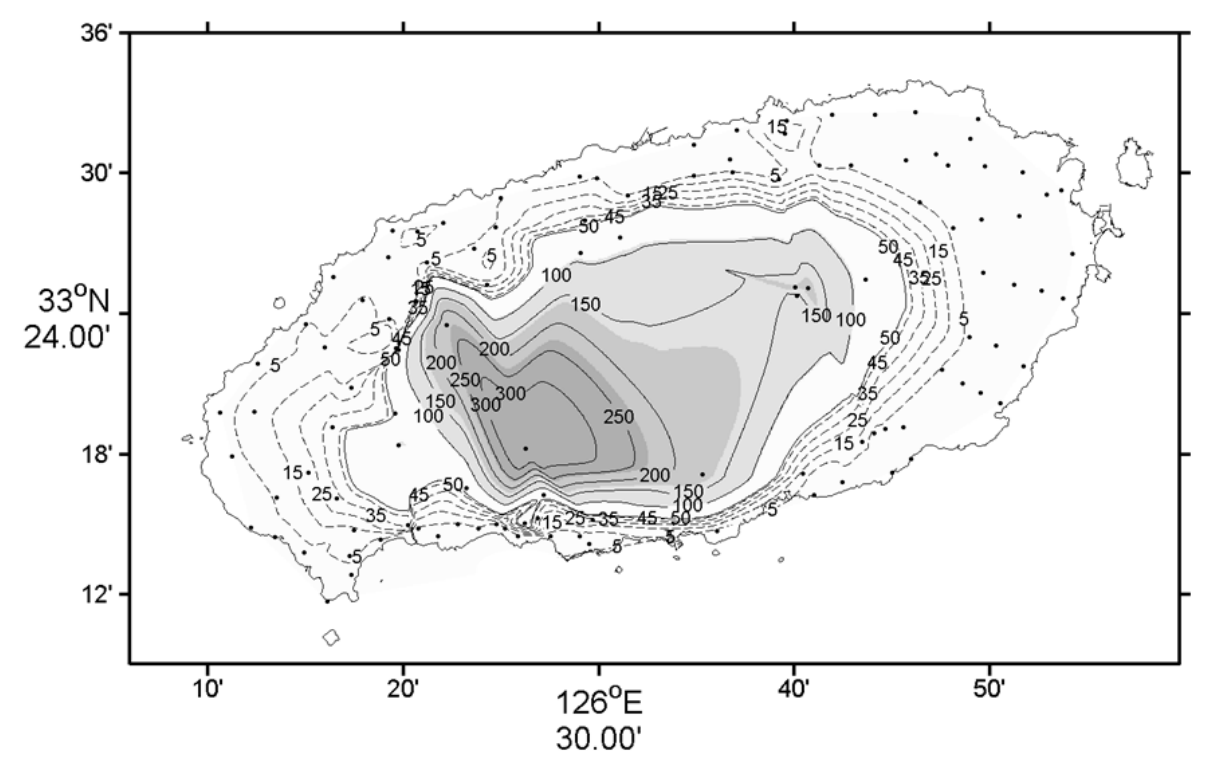

Fig. 7. Base level of groundwater in Jeju Island using the data of groundwater level from January 1, 2006 to July 31, 2009. Dashed lines and dark coloured zone indicate base levels of lower than $50 \mathrm{~m}$ and higher than $100 \mathrm{~m}$ above mean sea level, respectively.

\section{3. 지하수위 평균 상승폭}

제주도 전역에 걸친 지하수위 평균 상승폭도 역시 두 가지 방법으로 산정하였다. 하나는 각 관측정에서 지하수위 기준면으로부터 상승한 지하수위 상승폭을 각각 산정한 후 전 관측정에 대해 단순 평균한 것과, 이와 같이 구한 각 관측정의 상승폭을 제주도 전역에 걸쳐 내삽한 후 제주도 전역에 걸쳐 평균하여 산정한 것이다. 이와 같은 두 가지 방법으로 구한 함양부피는 차이가 많았다. 예를 들어 강수량이 많았던 2007년 9 월의 태풍 나리가 지나간 후 지하수위가 가장 높이 상 승했던 때의 평균 상승폭은 전자의 경우 $9.03 \mathrm{~m}$ 였고 후자인 경우 $14.73 \mathrm{~m}$ 였다. 이러한 차이는 지하수위를 측정하는 관측정이 대부분 지하수위의 변동이 작은 해안지역에 집중되어 있기 때문이다. 중산간 지역에 서는 강수 후 지하수위 상승폭이 크지만 관측정의 수 는 많지 않아 내삽하지 않고 단순히 평균할 경우 상승 폭이 작아진 것이다. 따라서 제주도 지하수위의 평균 상승폭은 후자와 같이 관측된 지하수위의 상승폭을 제주도 전역에 걸쳐 내삽한 후에 평균한 값이 더 실제 에 가깝다고 할 수 있다.
Fig. 8은 Fig. 7 의 지하수위 기준면으로부터 상승한 지하수면을 제주도 전역에 걸쳐 내삽한 후 평균하여 얻은 제주도 지하수위 평균 상승폭을 2001년 1월 1일 부터 2009년 7월 31일까지 시계열로 표시한 것이다. 2001년과 2002년 전반에는 지하수위 상승폭이 낮은 데, 그 이유는 2000년에 강수량이 매우 적었고 이듬해 인 2001년에 강수량이 평년보다 적어 충분하지 않았 기 때문으로 판단된다(Fig. 4). 그러나 2000년대 초반 에는 지하수위 관측정의 개수가 20 개미만으로 적었으 며 대부분 지하수위가 $200 \mathrm{~m}$ 보다 낮은 해안가에 위 치했기 때문에 지하수위 상승폭이 낮게 계산된 영향 도 작용했다고 판단된다(Fig. 3). 관측정 수가 30 개 이 상으로 불어나고 중산간에 관측정이 배치된 2003년 후에는 관측정의 수가 함양부피에 영향을 미치는 것 같지는 않다. 지하수위가 안정적으로 관측되기 시작 한 2003년 이후에 최저의 평균 상승폭은 2009년 초에 나타난 약 $0 \mathrm{~m}$ 이다. 2009년 초에 상승폭이 이렇게 낮 은 이유는 2008년도에 강수량이 적었기 때문이다. 2008년에는 년강수량이 약 $1,450 \mathrm{~mm}$ 로 적었고, 이 값은 제주도 평균 년강수량보다 약 $500 \mathrm{~mm}$ 적은 양 
이었다(Fig. 4). 2005년의 년강수량은 $1,420 \mathrm{~mm}$ 로 2008년보다도 약간 작았으나 2006년 초의 지하수위 상승폭은 2009년 초와 같이 낮아지지는 않았는데, 그 이유는 두 해의 강수량은 비슷했지만 2008년에는 강 수가 여름철에 집중된 것에 비해 2005년에는 여러 계 절에 걸쳐 강수 빈도수가 많았기 때문에 강수 후 지표 로 유출되는 양이 적었기 때문이다. 지하수위 기준수 위를 정할 때 각 관정에서 전 기간 중에서 가장 낮은 지하수위로 정했기 때문에 웬만큼 강수량이 적지 않 다면, 지하수면이 기준면까지 하강하기는 힘들다. 그 러나 2009년의 경우와 같이 전년도 강수량이 평년보 다 $500 \mathrm{~mm}$ 이상 적거나 이 정도는 아니더라도 2년 이 상 적은 강수량이 지속된다면 지하수면이 기준면 이 하로 하강할 가능성이 충분히 있으며 그럴 경우 지하 수위 하강으로 인한 해수침투 등의 문제가 발생할 수 있을 것이다. 상승폭이 큰 경우는 대부분 태풍이 지나 간 후이며 가장 높은 상승폭은 2007년 9월에 태풍 나 리 후의 $14.73 \mathrm{~m}$ 이다. 2003년부터 2009년 동안의 평 균 상승폭은 $5.43 \mathrm{~m}$ 이다.

지하수위 기준면으로부터 상승한 지하수면의 상승 폭을 계산하고 나면, 함양된 지하수에 대해 여러 가지 정보를 얻을 수 있다. 예를 들어 제주도 전역에 걸친 지하수위의 평균 상승폭을 비교함으로써 강수에 의한 지하수 함양량의 상대적인 비를 알 수 있으며, 강수 시 의 함양 속도와 비강수 시의 하강 속도를 알 수 있게 된다. 또한 지하수위 평균 상승폭에 제주도 면적을 곱
하면 함양부피를 구할 수 있다.

\section{4. 지하수 함양부피}

지하수위 기준면과 상승한 지하수면 사이의 부피 는 강수에 의해 지하수가 함양된 공간이며 본 연구에 서는 이 부피를 지하수 함양부피라고 하였다. 이 부피 는 지하수위 기준면과 상승한 지하수면 사이의 부피 를 적분하여 구할 수 있으며 2001년 1월 1일부터 2009년 7월 31일까지 제주도 전역의 함양부피 변동은 Fig. 8과 같다. Fig. 9에서 상승폭은 대체로 해안에 가 까울수록 작고 중산간 지역으로 갈수록 높다. 그러나 한라산 주변의 상승폭이 낮은 이유는 한라산 주변 지 역의 관측정이 없어 한라산 남북의 낮은 상승폭이 내 삽되었기 때문이다. 참고로 Fig. 7에서 한라산 남서쪽 의 지하수위 기준면을 높게 만든 중문 관정은 2008년 6월 17일부터 관측되기 시작했으며 태풍 나리 때에는 지하수위가 관측되지 않았다. 중문은 지하수위 상승 폭이 크므로 만약 태풍 나리 때 중문 관정의 지하수위 가 관측되었다면 실제 함양부피는 더 크게 계산되었 을 것이다. 태풍 나리에 의한 함양부피는 분석기간 중 최대였으며 제주도에서 지하수 함양의 최대부피라고 볼 수 있다. 평균 함양부피는 이에 비해 많이 작다. 2003년 1월 1일부터 2009년 7월 31일까지의 기간에 지하수위 평균 상승폭은 $5.43 \mathrm{~m}$ 이었으며 여기에 제주 도 면적인 $1.81 \times 10^{9} \mathrm{~m}^{2}$ 을 곱하면 이 기간 동안의 평 균 함양부피는 $9.83 \times 10^{9} \mathrm{~m}^{3}$ 라는 것을 알 수 있다.

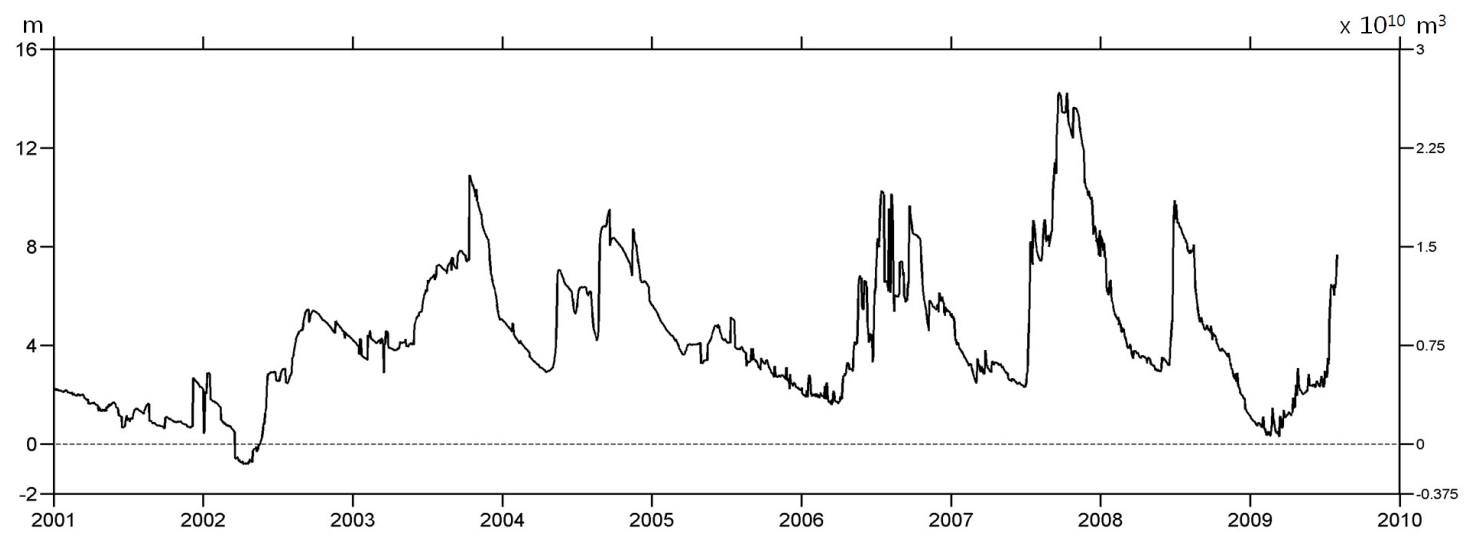

Fig. 8. Spacially mean groundwater level rise above the base level in Jeju Island (left vertical axis) and total recharge volume between the base level and the groundwater level (right vertical axis) from January 1, 2001 to July 31, 2009. 


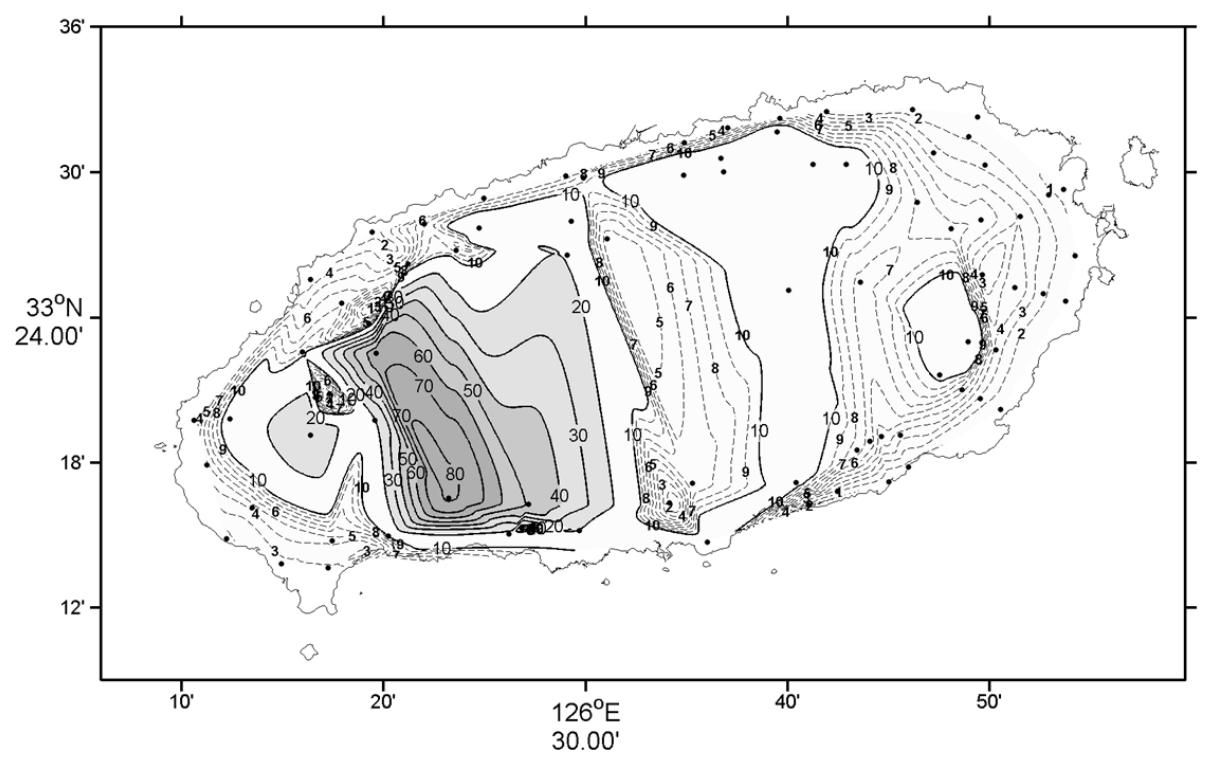

Fig. 9. The distribution of groundwater level rise above the base level in Jeju Island at the time of maximum recharge volume just after the typhoon Nari in 2007.

2001년과 2002년에는 관측정의 수가 많지 않고 지하 수위가 낮은 해안가에 분포하여 지하수위가 많이 낮 았기 때문에 두 해를 빼고 계산한 것이다.

2007년 9월 태풍 나리가 지나간 후의 구역별 함양 부피를 보면(Table 2) 가장 함양부피가 큰 구역은 면 적이 가장 넓은 7구역이며 가장 작은 구역은 면적이 가장 작은 1 구역이다. 그러나 한 격자 $\left(\left(2.59 \times 10^{5} \mathrm{~m}^{2}\right)\right.$ 에 함양되는 평균 함양부피를 보면 6구역이 가장 크며 3 구역이 가장 작다. 6 구역의 평균 함양부피는 3 구역 의 약 4.5 배에 이르는데 지역별 공극률의 차이가 많지
않다면 이것은 6 구역의 지하수 함양량이 가장 풍부하 다는 것을 의미한다.

함양부피의 변동(Fig. 8)은 강수량(Fig. 4)의 변동 과 비슷하다. 계절에 따른 함양부피의 변동을 보면 여 름철에 강수량이 많은 후에 함양부피가 증가하고 그 후에는 다음해 봄철에 강수가 다시 시작될 때까지 함 양부피가 점점 줄어들어 최저에 이르며 강수가 시작 되면 다시 증가한다. 일반적으로 강수량이 많은 해에 는 함양부피가 크고 강수량이 적은 해에는 함양부피 가 작다. 그러나 함양부피가 강수량과 반드시 비례하

Table 2. Mean groundwater level rise above the base level, mean recharge volume per each grid $\left(2.59 \times 10^{5} \mathrm{~m}^{2}\right)$, and total recharge volume in each section at the time of maximum recharge volume just after the typhoon Nari in 2007

\begin{tabular}{cccc}
\hline Section & $\begin{array}{c}\text { Mean height above the base level } \\
(\mathrm{m})\end{array}$ & $\begin{array}{c}\text { Mean recharge volume per grid }\left(2.59 \times 10^{5} \mathrm{~m}^{2}\right) \\
\left(\times 10^{6} \mathrm{~m}^{3}\right)\end{array}$ & $\begin{array}{c}\text { Total recharge volume } \\
\left(\times 10^{9} \mathrm{~m}^{3}\right)\end{array}$ \\
\hline \hline 1 & 9.04 & 2.41 & 0.90 \\
2 & 9.56 & 2.56 & 2.71 \\
3 & 6.89 & 1.84 & 2.75 \\
4 & 7.45 & 1.99 & 1.05 \\
5 & 14.23 & 3.80 & 1.71 \\
6 & 30.94 & 8.26 & 6.67 \\
7 & 25.25 & 6.74 & 9.14 \\
8 & 14.46 & 3.86 & 1.74 \\
\hline Mean & 14.73 & 3.93 & (Total) 26.67 \\
\hline
\end{tabular}


는 것은 아니다. 함양부피는 2007년에 최대가 되었지 만 강수량은 2007년보다 2003년이 더 많았다(Fig. 4). 2003년에는 봄철부터 가을에 걸쳐 강수빈도가 많았 던 것에 비해 2007년에는 태풍 나리에 의해 강수량이 집중되었으며 이로 인해 2007년에는 지표를 통해 바 다로 유출된 양이 많아졌기 때문이다. 즉, 강수량과 함 께 강수빈도도 함양부피에 영향을 준다는 것을 알 수 있다. 함양부피의 변동을 보면 대부분 여름철의 풍부 한 강수에 의해 지하수가 충분히 채워져 겨울철의 가 뭄에도 제주도에서 지하수의 부족은 없는 것으로 보 인다. 그러나, 2005 년과 2008 년과 같이 여름철의 강 수량이 적을 때는 지하수가 충분히 채워지지 않아, 이 어지는 겨울철에 함양부피가 기준면까지 줄어들었다. 다행히 2006년과 2009년 여름에 강수량이 지하수를 채우기에 충분했기 때문에 별 문제없이 지나갔지만 2000년과 2001년과 같이 여름철 강수량이 적은 해가 두 번 이어지면 지하수면이 기준면보다 낮아져 해수 침투 등의 문제가 발생하고 심할 경우 지하수 양적인 문제도 발생할 수도 있을 것이다.

\section{5. 지하수 함양량과 유효공극률}

앞 절에서는 지하수위 변동으로부터 함양부피를 산정할 수 있었다. 그러나 지하수위 변동만으로는 함 양량을 구할 수는 없다. 이 절에서는 함양부피를 활용 하여 함양량을 구할 수 있는 방법을 제시해 보았다. 함 양부피로부터 함양량을 구하려면 공극률이 필요하지 만 이에 대한 연구가 제대로 이루어지지 않았다. 한 등 (1994)은 공극률과 비슷한 개념인 저유계수(specific yield)를 도입하여 산정하였는데, 제주도의 평균 저유 계수를 $12 \%$ 로 보고하였다. 이 절에서는 제주도 수문 지질 및 지하수자원 종합조사(2003)에서 추산한 함양 률 $46.1 \%$ 를 적용하여 강수량으로부터 지하수 함양량 을 구하고 그 함양량과 앞에서 구한 함양부피로부터 제주도 전체의 평균 유효공극률을 추정하여 보았다. 유효공극률은 지하수가 유입되어 채워진 공극률로서 지질의 특성이라기보다는 지하수 흐름의 특성으로서 시간에 따라 변화하는 값이며 이 논문에서는 태풍 후 의 극단적인 경우와 분석기간 동안 평균의 경우로부 터 평균 유효공극률의 범위를 제시하였다(참고로, 평 균에는 제주도 전체의 공간 평균과 분석 기간 전체의
시간 평균이 있데 평균 유효공극률의 평균은 제주도 전체의 공간 평균이다.). 단, 시간 평균의 경우에는 제 주도 수문지질 및 지하수자원 종합조사(2003)에서 추 산한 함양률 $46.1 \%$ 를 적용하는 것에 무리가 없으나 태풍 후의 극단적인 경우에는 지표를 통해 유출되는 빗물의 양이 많기 때문에 함양률은 이보다 작을 것이 다. 그러나 현재로서는 태풍과 같이 많은 비가 내렸을 때 어느 정도의 빗물이 지표를 통해 유출되는지 연구 된 자료가 없기 때문에 무리임에도 불구하고 함양율 $46.1 \%$ 를 적용하여 유효공극률을 산출하였다. 이 문제 는 앞으로 연구되어야 할 과제 중의 하나이다.

우선 분석기간 동안의 평균 유효공극률을 구하였 는데 2001년과 2002년에는 관측정의 수가 많지 않고 지하수위가 낮은 해안가에 분포하여 지하수위가 많이 낮았기 때문에 두 해를 빼고 평균 유효공극률을 구하 였다. 2003년 1월 1일부터 2009년 7월 31일 동안의 평균 함양부피와 평균 강수량으로부터 평균 유효공극 률은 다음과 같이 구할 수 있다. 이 기간 동안의 평균 함양부피는 $9.83 \times 10^{9} \mathrm{~m}^{3}$ 이며 평균 강수량은 평균 면 적강수량인 $1,973 \mathrm{~mm}$ 에 제주도 면적 $\left(1.81 \times 10^{9} \mathrm{~m}^{2}\right)$ 을 곱한 $3.57 \times 10^{9} m^{3}$ 이다. 이 평균 강수량에 제주도 가 추산한 함양률 $46.1 \%$ 를 적용하면 함양량은 $1.65 \times 10^{9} \mathrm{~m}^{3}$ 가 된다. 그러므로 이 함양량과 평균 함 양부피로 구한 제주도 평균 유효공극률은 $16.8 \%$ 이다.

다음으로 2001년 1월 1일부터 2009년 7월 31일 동 안에 나타난 최대 함양부피와 그 때의 강수량으로부 터 구한 제주도 전체의 평균 유효공극률은 다음과 같 다. 최대 함양부피는 2007년 9월 16일 태풍 나리에 의 해 발생하였는데 지하수위는 태풍 “나리” 가 지나가기 전인 7월의 장마로 상승하기 시작하였으며 최대 함양 부피는 태풍 “나리”에 의한 최대 강수량이 내린 다음 약 5 일 후에 $2.667 \times 10^{10} \mathrm{~m}^{3}$ 로 계산되었다. 2007 년 여 름의 장마가 시작된 7월 7일부터 최대 함양부피가 나 타난 9 월 21 일까지의 면적 강수량은 $1,442 \mathrm{~mm}$ 로 이 기간 동안 강수량은 $2.665 \times 10^{9} \mathrm{~m}^{3}$ 이었다. 이 강수량 에 제주도가 추산한 함양률 $46.1 \%$ 를 적용하면 함양량 은 $1.23 \times 10^{9} \mathrm{~m}^{3}$ 이다. 그러므로 최대 함양부피로 구 한 제주도 평균 유효공극률은 $4.6 \%$ 이다.

두 방법에 의한 공극률이 차이가 많은 것은 비가 온 
직후에 지하로 유입된 지하수가 공극을 채우는데 많 은 시간이 필요하다는 것을 의미한다. 즉, 강수 후 지 하로 유입된 지하수가 공극을 즉시 다 채우는 것이 아 니라 시간이 지나며 공극을 채워가기 때문이다. Fig. 8 에서와 같이 비가 온 후에 시간이 지나면서 함양부피 가 낮아지는 것은 지하수가 하천이나 바다로 유출되 기 때문이기도 하지만 강수 직후에 지하로 스며든 지 하수가 밑으로 흘러 내려가며 아직 채워지지 않은 빈 공간을 채우기 때문이다. 다음절의 결과는 이 기간이 제주도 전역의 평균으로 89 일 정도라는 것을 보여준 다(Table 3). 그러므로 여기서 말하는 유효공극률은 지질의 공극률이 자체가 아니라 지하수로 채워진 공 극률을 말하는 것이다. 이상의 결과를 보면 제주도의 평균 유효공극률은 비가 온 직후에는 약 $5 \%$ 이다가 시 간이 지나며 점점 높아져 약 $17 \%$ 까지 높아지는 것으 로 판단할 수 있다. 이와 같이 구한 제주도 평균 유효 공극률에는 많은 오차들이 포함되어 있으나 평균 유 효공극률의 범위를 제공함으로써 지하수위의 변동으 로부터 지하수 함양량을 대략적으로 추정할 수 있는 방법을 제공해 주는 것으로 의의를 찾을 수 있다.

\section{6. 강수량과 지하수위의 상관관계}

이 장에서는 강수량이 최대인 시점인 2007년 9월 전후로 하여 강수량과 지하수위의 변화와의 상관관계 를 구해 보았다. 기간은 태풍 “나리”가 오기 90일 전 부터 태풍이 지나간 후 260 일까지 총 340 일(2007년 6 월15일 부터 2008년 5월 31일까지) 동안이다. 우선, 제주도 전역에서 강수량과 지하수위의 평균 상관관계 는 0.47 로 계산되었다. 지하수위의 변화에 가장 큰 영 향을 미치는 것이 강수량이기 때문에 상관관계가 클 것으로 예상되었으나 기대만큼 크지는 않았다. 그 이 유는 강수량이 많을 때는 지하수위가 강수량에 의해 상승하지만 강수량이 자연 유출량이나 인간이 이용하 기 위해 양수하는 양보다 작을 경우 지하수위는 상승 하지 않기 때문이다.

강수량에 대한 지하수위의 반응을 알아보기 위해 최고 강수량이 내린 후 지하수위 상승폭, 강수 후 최고 수위에 도달하는 데 걸리는 시간과 다시 낮은 수위로 돌아가는데 걸린 시간을 지역별로 구하였다(Table 3). 최대 강수량이 단 시간에 이루어진 것이 아니며 또한
최대 강수량 전후에도 다른 강수량들이 있어 최대 강 수량이 발생한 시각과 그로 인한 수위 상승이나 하강 이 시작한 시각들을 명확하게 정하기는 쉽지 않다. 이 들의 시기를 어느 시점을 기준으로 하느냐에 따라 기 간이 달라지며 또한 최고 강수량 전후에도 다른 강우 들이 있어 최고, 최저 수위에 도달하는 시각이 명확하 게 구분되지는 않는다. 그럼에도 불구하고 이러한 시 간들은 지하수위가 강수에 얼마나 빨리 반응하는지를 가늠할 수 있게 해 준다. 전반적으로 상승폭은 동쪽에 비해 서쪽이 높은 편이다. 최고 강수량에 의해 최고 수 위에 도달하는 시간은 제주도 전역의 평균이 약 9.2 일 이며 다시 빠르게 하강하여 상승 전의 수위로 돌아오 는 기간은 제주도 전역의 평균이 약 89 일이다. 이 시 간 후에는 지하수위가 매우 서서히 하강하고 있다. 동 쪽 지역은 다른 지역에 비해 최고 수위에 도달하는 시 간이 짧으며 최저 수위에 도달하는 시간은 길다.

이 논문에서는 강수량에 대한 지하수위의 상승도 와 비가 오지 않을 경우 지하수위의 하강도를 Table 3 와 같이 정의하여 계산하였다. 강수량에 대한 지하수 위의 상승도는 상승폭을 강수량과 최고수위에 도달하 는 시간을 나눈 것으로 값이 클수록 강수량에 대한 반 응이 큰 것이며 비가 오지 않을 경우 지하수위의 하강 도는 하강폭을 최저수위에 도달하는 시간으로 나눈 값으로 역시 값이 클수록 지하수위가 빠르게 하강하 는 것을 의미한다. 이들 값들은 임의의 값으로서 절대 적인 값에는 의미가 없으며 상대적인 의미를 갖는다. 계산 결과 강수에 대한 지하수위의 상승 반응이나 지 하수위의 하강 변화 모두 서쪽 지역이 동쪽 지역에 비 해 크다.

이상의 결과를 종합해 보면 강수에 의한 지하수위 상승은 동쪽 지역이 작으며 빠르고 서쪽 지역이 높고 느린데 비해 비가 오지 않을 경우 지하수위의 하강 반 응은 반대로 동쪽 지역이 느리고 서쪽 지역이 빠르게 나타났다. 이것은 동쪽 지역의 투수성이 좋아 강수에 의한 지하수 함양 속도는 빠르나 지하수위가 낮게 형 성되기 때문에 하강속도는 느리게 반응하는 것으로 해석할 수 있다(이 등(2006)). 이러한 값들은 강수기 의 지하수위의 변동과 무강우 기간에 따른 지하수위 의 변동을 추정하는 데 사용될 수 있으며 특히 가뭄의 장기화 또는 지하수의 과다한 사용으로 인한 급격한 
Table 3. Relationships between precipitation and groundwater level before and after heavy precipitation by typhoon Nari in 2007

\begin{tabular}{cccrrrrrr}
\hline Section & $\begin{array}{c}\text { Base } \\
\text { Level } \\
\left(L_{b}\right)\end{array}$ & $\begin{array}{c}\text { Highest } \\
\text { level } \\
\left(L_{m}\right)\end{array}$ & $L_{m}-L_{b}$ & $\begin{array}{c}\text { Time to } \\
\text { highest level } \\
\left(T_{r}\right)\end{array}$ & $\begin{array}{c}\text { Time to lowest } \\
\text { level }\left(T_{d}\right)\end{array}$ & $\begin{array}{c}\text { Precipitation } \\
\left(P_{r}\right)\end{array}$ & $\frac{L_{m}-L_{b}}{P_{r} T_{r}}$ & $\frac{L_{m}-L_{b}}{T_{d}}$ \\
\hline \hline 1 & 23.76 & 36.75 & 12.99 & 11.4 & 90.3 & 439.0 & $2.596 \mathrm{E}-03$ & $1.439 \mathrm{E}-01$ \\
2 & 11.35 & 18.26 & 6.91 & 7.6 & 102.3 & 495.4 & $1.831 \mathrm{E}-03$ & $6.752 \mathrm{E}-02$ \\
3 & 1.39 & 6.65 & 5.26 & 5.7 & 104.8 & 363.8 & $2.524 \mathrm{E}-03$ & $5.018 \mathrm{E}-02$ \\
4 & 3.30 & 7.80 & 4.50 & 7.6 & 101.4 & 392.7 & $1.515 \mathrm{E}-03$ & $4.432 \mathrm{E}-02$ \\
5 & 66.42 & 88.29 & 21.67 & 10.2 & 100.8 & 440.0 & $4.828 \mathrm{E}-03$ & $2.150 \mathrm{E}-01$ \\
6 & 17.14 & 33.00 & 15.85 & 7.9 & 44.4 & 218.3 & $9.244 \mathrm{E}-03$ & $3.568 \mathrm{E}-01$ \\
7 & 14.32 & 31.78 & 17.46 & 10.4 & 76.8 & 282.0 & $5.927 \mathrm{E}-03$ & $2.274 \mathrm{E}-01$ \\
8 & 4.18 & 11.06 & 6.89 & 12.5 & 98.8 & 508.3 & $1.084 \mathrm{E}-03$ & $6.975 \mathrm{E}-02$ \\
\hline Mean & 17.73 & 29.20 & 11.44 & 9.2 & 89.0 & 392.4 & $3.169 \mathrm{E}-03$ & $1.285 \mathrm{E}-01$ \\
\hline
\end{tabular}

수위 강하 등의 문제가 발생할 경우 사용량을 관리할 수 있는 지하수위를 파악하는 데에도 사용할 수 있을 것이다. 관리가 필요한 지하수위는 앞으로 더 연구되 어야 할 과제지만 우선은 제주도의 지하수위 기준면 을 활용 수 있을 것으로 생각한다.

\section{4. 결 론}

이 논문에서는 지하수를 지속적으로 이용하기 위 해 필요한 정보를 얻고자 지하수의 공급원인 강수량 과 지하수위의 변화를 분석하였다. 1992년부터 2008 년까지 중산간 및 고지대 지역을 포함한 제주도 전역 에서 관측된 강수량 자료를 분석한 결과 제주도 전체 의 연평균 강수량은 $1,973 \mathrm{~mm}$ 이었다. 해발고도가 높 아질수록 강수량은 많아져 한라산 부근에는 약 3,600 $\mathrm{mm}$ 이상까지 나타났으며 지역별로는 성판악이 3,727 $\mathrm{mm}$ 로 가장 많았고 고산2 지역이 $1,120 \mathrm{~mm}$ 로 가장 적 었다. 분석기간 동안 지하수위를 가장 높게 만들었던 호우는 2007년 9월 16일 태풍 나리에 의한 것이었으며 제주도 전역에 걸쳐 일평균 $250 \mathrm{~mm}$ 정도의 강수가 내 렸다.

강수 후 지하수위가 상승하는 정도를 알아보기 위 해 이 논문에서는 지하수위 기준면을 정하였는데 지 하수위 기준면은 강수가 없을 때 각 관측정에서 지하 수위가 안정적으로 유지되는 최저 지하수위를 연결한 면이다. 지하수위 기준면은 해안에서 중산간 지역으 로 갈수록 높아지는데 동쪽 지역에서는 $50 \mathrm{~m}$ 이하의 기준면이 폭넓게 분포하며 남쪽에서는 폭이 매우 좁
다. 년중 강수가 여름철에 집중되기 때문에 계절에 따 른 지하수위의 변동은 여름철의 강수 후에 가장 많이 상승하고 그 후에는 하강하여 다음해 봄철의 강수 전 에 가장 많이 하강한다. 2003-2009년 기간 동안 제주 도 전역에서 강수에 의한 지하수위의 평균 상승폭은 $5.43 \mathrm{~m}$ 이며 상승폭이 큰 경우는 대부분 태풍이 지나 간 후로 가장 높은 상승폭은 2007년 9월에 태풍 “나 리" 이후 $14.73 \mathrm{~m}$ 이었다. 이 기간 동안 최저의 상승폭 은 전년도에 강수량이 적었던 2009년 초에 나타났으 며 상승폭은 약 $0 \mathrm{~m}$ 정도이다. 2003-2009년 동안 겨 울철에 낮아지는 지하수위가 어느 정도의 수위를 유 지하는 것으로 보아서는 여름철의 풍부한 강수에 의 해 겨울철의 가뭄에도 제주도에서 지하수의 부족은 없어 보인다. 그러나 만약 여름철의 강수량이 충분하 지 않거나 또는 강수량이 적은 해가 2 년 이상 연속된 다면 지하수위는 기준면 이하로 하강하여 해수침투 등의 문제가 발생할 수도 있을 것이다.

지하수면의 상승으로부터 강수에 의한 지하수 함 양부피를 구할 수 있는데 함양부피는 지하수위 기준 면과 상승한 지하수면 사이의 부피이며 그 사이에 지 하수가 함양되어 있는 체적이다. 2003년부터 2009년 동안 제주도 전역의 평균 함양부피는 $9.83 \times 10^{9} \mathrm{~m}^{3}$ 이 며 최대 함양부피는 2007년 9월 태풍 나리 후의 $2.667 \times 10^{10} \mathrm{~m}^{3}$ 이다. 단위 면적당 함양부피가 가장 큰 6 구역이 가장 작은 3 구역의 약 4.5 배에 이르는데 이것 은 지역별 공극률의 차이가 많지 않다면 6 구역의 지하 수 함양량이 가장 풍부하다는 것을 의미한다. 이렇게 
구한 함양부피와 제주도 수문지질 및 지하수자원 종 합조사(2003)에서 추산한 함양률 $46.1 \%$ 를 적용하여 얻은 함양량으로부터 제주도의 전역의 평균 유효공극 률을 구한 결과, 2003년부터 2009년 동안의 평균은 약 $16.8 \%$ 이며 2007년 9월에 최대 함양부피가 나타났 을 때는 약 $4.6 \%$ 였다. 여기서 구한 유효공극률은 지질 의 공극률이 자체가 아니라 지하수로 채워진 공극률 을 의미하는 것으로, 두 방법에 의한 유효공극률이 차 이가 많은 것은 비가 온 직후에 지하로 유입된 지하수 가 공극을 채우는데 많은 시간이 필요하다는 것을 의 미한다. 비가 온 후에 시간이 지나면서 함양부피가 낮 아지는 것은 지하수가 하천이나 바다로 유출되기 때 문이기도 하지만 강수 직후에 지하로 스며든 지하수 가 밑으로 흘러 내려가며 아직 채워지지 않은 빈 공간 을 채우기 때문이다. 그러므로 지하수로 채워진 제주 도의 평균 유효공극률은 비가 온 직후에는 약 $5 \%$ 이다 가 시간이 지나며 점점 높아져 약 $17 \%$ 까지 높아지는 것으로 판단할 수 있다. 이러한 계산에는 많은 오차들 이 포함되어 있으나 제주도의 평균 유효공극률의 범 위를 제공함으로써 지하수위 변동으로부터 현재의 지 하수 함양량을 대략적으로 추정할 수 있는 방법을 제 공한다.

제주도 전역에서 강수량과 지하수위의 평균 상관 관계는 0.47 로 높지 않았다. 그 이유는 강수량이 많을 때는 지하수위가 강수량에 의해 바로 상승하지만 강 수량이 적을 때는 자연 유출량이나 지하수의 이용량 등에 의해 지하수위가 상승하지 못하고 계속 하강하 므로 전체적으로 보면 강수량이 지하수위를 항상 결 정하지는 못하기 때문이다. 다른 이유는 강수가 많을 때는 지하수위가 빨리 상승하지만 비강수기에는 지하 수위가 느리게 하강하기 때문이다. 그러나, 낮은 상관 관계가 강수량의 중요도를 떨어뜨리는 것은 아니다. 강수량이 많을 때의 관계가 중요하기 때문이다. 지하 수위의 변화가 강수에 반응하는 정도를 지역별로 분 석한 결과 강수에 의한 지하수위 상승은 동쪽 지역이 작으며 빠르고 서쪽 지역이 높고 느린데 비해 비가 오 지 않을 경우 지하수위의 하강 반응은 반대로 동쪽 지 역이 느리고 서쪽 지역이 빠르게 나타났다. 이것은 동 쪽 지역의 투수성이 좋아 강수에 의한 지하수 함양 속 도는 빠르나 지하수위가 낮게 형성되기 때문에 하강
속도는 느리게 반응하는 것으로 판단된다.

지금까지 제주도내 지하수의 함양량은 강수량으로 부터 계산된 수자원 총량에서 증발산량과 하천 유출 량 등을 뺀 값으로 계산되고 있다. 하지만 그동안 지하 수위의 관측정이 도 전역에 설치되어 관측이 이루어 지고 있기 때문에 이 연구에서와 같이 지하수위 변동 을 이용한 방법을 차용하여 비교 검토하는 것도 좋을 것으로 제안한다. 이 방법에도 절대적인 함양량 계산 에는 불확실성에 따른 오차가 있지만, 상대적인 함양 량에 대한 정보를 제공해 주며 앞으로 정확한 공극률 의 산정과 지하수위 관측으로부터 지하수위로부터 직 접 함양량을 구할 수 있는 가능성을 제시한 것에 의의 를 찾을 수 있다.

\section{감사의 글}

본 논문은 교육과학기술부의 재원으로 한국연구재 단의 지원을 받아 수행된 광역경제권 선도산업 인재 양성사업의 연구비와 기상청의 지역기후서비스 사업 의 연구비로 수행된 결과입니다.

\section{참 고 문 헌}

김규범, 이명재, 김정우, 이진용, 이강근, 2004, 수위강하 곡선을 이용한 함양량 추정기법의 국가 지하수 관측 소 지하수위 자료에의 적용성 평가, The Journal of Engineering Geology, 14(3), 313-323.

김경호, 윤영호, 조재희, 박재성, 1998 , 건설기술연구소 논문집, 17(2), 175-182.

김태원, 함세영, 정재열, 류상민, 이정환, 손건태, 김남훈, 2008 , 금정산지역의 수위변동 자료를 이용한 시계 열 및 지하수 함양량 분석, 한국환경과학회지, 17(2), 257-267.

문상기, 우남칠, 2001, 누적 강수량과 지하수위 곡선을 이용한 지하수 함양률 추정기법, 지하수토양환경, 6(1), 33-43.

문상기, 우남칠, 이광식, 2002, 지하수위 유형과유역별 지하수 함양률의 관련성연구: 국가 지하수 관측망 자료의 분석, 지하수토양환경, 7(3), 45-59.

박재성, 김경호, 전민우, 김지수, 1999 , 소유역의 지하수 함양율 추정기법, 지하수환경, 6(2), 76-86.

박창희, 2002, 국가 지하수 관측망의 수위 및 온도 자료 
를 이용한 함양량 산정, 석사학위논문, 공주대학교. 수자원장기종합계획(2006-2020), 2006, 건설교통부.

이봉주, 구민호, 박윤석, 고기원, 박기화, 2006, 제주 동부 지역의 수리확산계수와 지하수 도관 유동 가능성, 지질학회지, 42(3), 439-454.

이상덕, 2007, 광릉 소유역 내 원두부 지역의 지하수 함 양량 산정과 지하수위 변동 분석, 석사학위논문, 연 세대학교.

제주도, 한국수자원공사, 2003. 제주도 수문지질 및 지하 수자원 종합조사(3차).

제주특별자치도, 2010 , 기후변화 영향평가 및 적응모델 개발. 최병수, 안중기, 1998 , 지역단위 지하수 자연 함양율 산 정방법 연구, 지하수환경, 5(2), 57-65.

한정상, 한규상, 김창길, 김남종, 한 찬, 1994. 제주도 지 하수자원의 최적 개발가능량, 대한지하수환경학회 지, 1(1), 33-50.
Healy, R. W., Cook, P. G., 2002, Using groundwater levels to estimate recharge, Hydrogeology Journal, 10, 91-109.

Moon, S. K., Woo, N. C., Lee, K. S., 2004, Statistical analysis of hydrographs and water-table fluctuation to estimate groundwater recharge, Journal of Hydrology, 292(1-4), 198-209.

Scanlon, B. R., Healy, R. W., Cook, P. G., 2002, Choosing appropriate techniques for quantifying groundwater recharge, Hydrogeology Journal, 10, 18-39.

Solomon, D. K., Sudicky, E. A., 1991, Tritium and helium-3 isotopic ratios for direct estimation of spatial variations in groundwater recharge, Water Resources Research, 27, 2309-2319. 